\title{
Retinal involvement of coronavirus disease (COVID-19): A systematic review
}

Mohammad Eko Prayogo, ${ }^{1}$ Angela Nurini Agni, ${ }^{1}$ Tri Wahyu Widayanti, ${ }^{1}$ Supanji, ${ }^{1}$ Firman Setya Wardhana, ${ }^{1}$ Muhammad Bayu Sasongko, ${ }^{1}$ Cita Shafira Amalia, ${ }^{2}$ Ni Putu Yena Yossiana Devi, ${ }^{2}$ Roihan Mohamad Iqbal, ${ }^{2}$ Vania Permatahati ${ }^{2}$

'Department of Ophthalmology, Faculty of Medicine, Public Health, and Nursing, Universitas Gadjah Mada, Yogyakarta, Indonesia

²Ophthalmology Research Unit, Faculty of Medicine Public Health, and Nursing, Universitas Gadjah Mada, Yogyakarta, Indonesia

KEYWORDS COVID-19

Ocular manifestation Retinal manifestation Viral infection
ABSTRACT COVID-19 has wide-ranging manifestations which involve various organs. Although COVID-19 is known to affect mainly the respiratory system, many patients suffered from ocular manifestations following SARS-CoV-2 infection, especially conjunctivitis. However, there was some evidence of broader ocular involvement, which could involve the retinal layer. This review aims to analyze the possible explanation of retinal involvement in COVID-19 and whether comorbidities increase the risk of retinal involvement in COVID-19. We conducted a systematic literature search during September 2020 using the PUBMED database and other additional sources (e.g., Google Scholar). There was no year of publication nor language restrictions. Six papers are used in this literature review: two studies reported retinal lesions in COVID-19 patients, one study detected SARS-CoV-2 RNA in retinal biopsies and three studies proposed possible mechanisms of retinal involvement in COVID-19. Ocular structures express ACE-2, such as the aqueous humor, pigmented epithelium, and retina. This is supported by the finding of SARSCoV-2 nucleic acid in postmortem patients. Retinal involvement in COVID-19 patients includes hyperreflective retina lesions, subtle cotton wool spots, and microhemorrhage. However, these findings do not necessarily indicate the specificity of retinal involvement. Diabetes mellitus may be associated with disease severity in patients with COVID-19. Some evidence of retinal involvement in SARS-CoV-2 infection involves the detection of retinal lesions, the expression of ACE-2 in the retina, and the role of comorbidities.

(c) The Journal 2021. This article is distributed under a Creative Commons Attribution-ShareAlike 4.0 International license.

\section{Introduction}

Coronavirus Disease 2019 (COVID-19), detected for the first time in late 2019 in Wuhan City, Hubei Province, China, had infected more than 26,121,999 and killed 864,618 people worldwide by September of 2020. ${ }^{1}$ COVID-19 is an infection caused by the Severe Acute Respiratory Syndrome-related Coronavirus 2 (SARS-CoV-2). SARS-CoV-2 is an enveloped, nonsegmental, positive-sense RNA virus belonging to the Coronaviridae family. ${ }^{2}$ After it rapidly spread worldwide, the World Health Organization (WHO) declared COVID-19 as a Public Health Emergency

\footnotetext{
*Correspondence: mohammad.eko.prayogo@ugm.ac.id Department of Ophthalmology, Faculty of Medicine, Public Health, and Nursing, Universitas Gadjah Mada. Jl. Farmako, Sekip Utara, Yogyakarta
}

of International Concern on January 30th, 2020 and then announced the disease as a global pandemic on March $11^{\text {th }} 2020 .^{3}$

The SARS-CoV-2 infection shows various manifestations, ranging from asymptomatic to Acute Respiratory Distress Syndrome (ARDS), and even death, especially when comorbidities such as diabetes mellitus (DM) and hypertension are present. ${ }^{4,5}$ Symptoms that are generally found in patients with COVID-19 are fever (>90\%), dry cough (60-85\%), anosmia and/or ageusia (60-80\%), dyspnea (53-80\%), nausea/vomit or diarrhea (15-39\%), and myalgia (15$44 \%) .^{6-13}$ The complications of COVID-19 infection involve the dysfunction of various organs such as lungs, heart, brain, liver, kidney, and hemostatic function. These organ dysfunctions manifest as myocarditis, cardiomyopathy, ventricular arrhythmia, 
acute cerebrovascular disease, encephalitis, and arterial/venous thrombo-embolization. ${ }^{6,14-17}$

Ocular manifestations of COVID-19 infection have been reported, but these are rare and often went undiagnosed. Conjunctivitis, as one of the wellknown ophthalmic involvements of COVID-19, has a prevalence of $32 \%$. Conjunctivitis was reported to occur mostly in patients suffering from severe infection with systemic symptoms. ${ }^{18,19}$ However, there were some possibilities that other eye structures may also be involved. A study by Marinho et al. (2020) reported changes in the retina of COVID-19 patients with ophthalmic involvement which manifested as microhemorrhages and cotton wool spots. ${ }^{20}$ Ocular manifestations on COVID-19 patients may correlate with the mechanism of viral entry into human cells.

SARS-CoV-2 infection is mediated by the binding of coronavirus spike protein to the cellular angiotensinconverting enzyme 2 (ACE-2) and by serine protease TMPRSS2, which promotes spike protein priming. ${ }^{21}$ The ACE-2 are expressed by lung cells (epithelial cells), heart cells, gut, kidney, and bladder. ${ }^{22}$ The increase in ACE-2 expression in those organs might be elicited by the use of DM and hypertension drugs such as ACE-2 inhibitors (ACEIs) and angiotensin II receptor blockers (ARBs). ${ }^{23}$ Some evidence of ACE-2 expression in conjunctiva and the cornea allowed for the detection of SARS-CoV- 2 in the tears of infected patients. ${ }^{18}$ These findings support the pathogenesis of conjunctivitis as one of the ocular manifestations of COVID-19 infection. However, there are still limited explanations regarding severe ocular manifestations of SARS-CoV-2 disease, especially those involving the retina which may lead to vision loss. This review aims to analyze the possible pathogenesis of retinal dysfunction in COVID-19 patients and the correlation of the retinal changes with co-morbidities such as DM and hypertension.

\section{Method}

\subsection{Literature search}

A systematic literature search was conducted during September 2020 using the PubMed database and other additional sources (e.g.Google Scholar) with the following search terms: "COVID-19" OR, "coronavirus" OR "SARS-CoV-2", AND "retina". There were no year of publication nor language restrictions.

\subsection{Data extraction and synthesis}

The articles were examined and the data were extracted into a table to identify COVID-19 diagnostic protocol, patient selection criteria, and ocular manifestations especially those involving the retina. We included original articles, editorial, and letters to editors due to the scarcity of publications regarding retinal manifestations in COVID-19.

\subsection{Statistical analysis}

We descriptively analyzed the total and median or range of age of subjects in Table 1.

\section{Results}

Table 1 summarizes the most recent studies regarding retinal involvement in SARS-CoV-2 infection. A study by Marinho et al. (2020) found that all COVID-19 patients showed hyper-reflective lesions at the level of ganglion cell (GC) and inner plexiform (IP) layers more prominently at the papillomacular bundle in both eyes. Four patients (33.3\%) presented subtle cotton wool spots and microhemorrhage. ${ }^{20}$

Landecho et al. (2020) found five patients with unilateral elliptical cotton wool spots and one case bilateral, including one patient who did not develop pneumonia. In cases that required orotracheal intubation, there were no cotton wool spots at the moment of funduscopic examination, 58 days after diagnosis. All patients received a daily prophylactic dose of low molecular weight heparin between the COVID-19 diagnosis and the funduscopic evaluation. ${ }^{24}$

Casagrande et al. (2020) found that in three out of 14 eyes, SARS-CoV-2 RNA was detected in the retina of deceased COVID-19 patients. These results were obtained from the analysis of three different sequences ( $R d R p$ gene, $E$ gene, and Orf1 gene). ${ }^{25}$

Raony and Saggioro (2020) proposed that DM may be associated with COVID-19 severity. DM might increase the risk of retinal lesions in patients with COVID-19 (e.g., lesions in GC and IP layers), with the involvement of CD147 and proinflammatory cytokines. ${ }^{26}$ Vavvas et al. (2020) stated that reported 


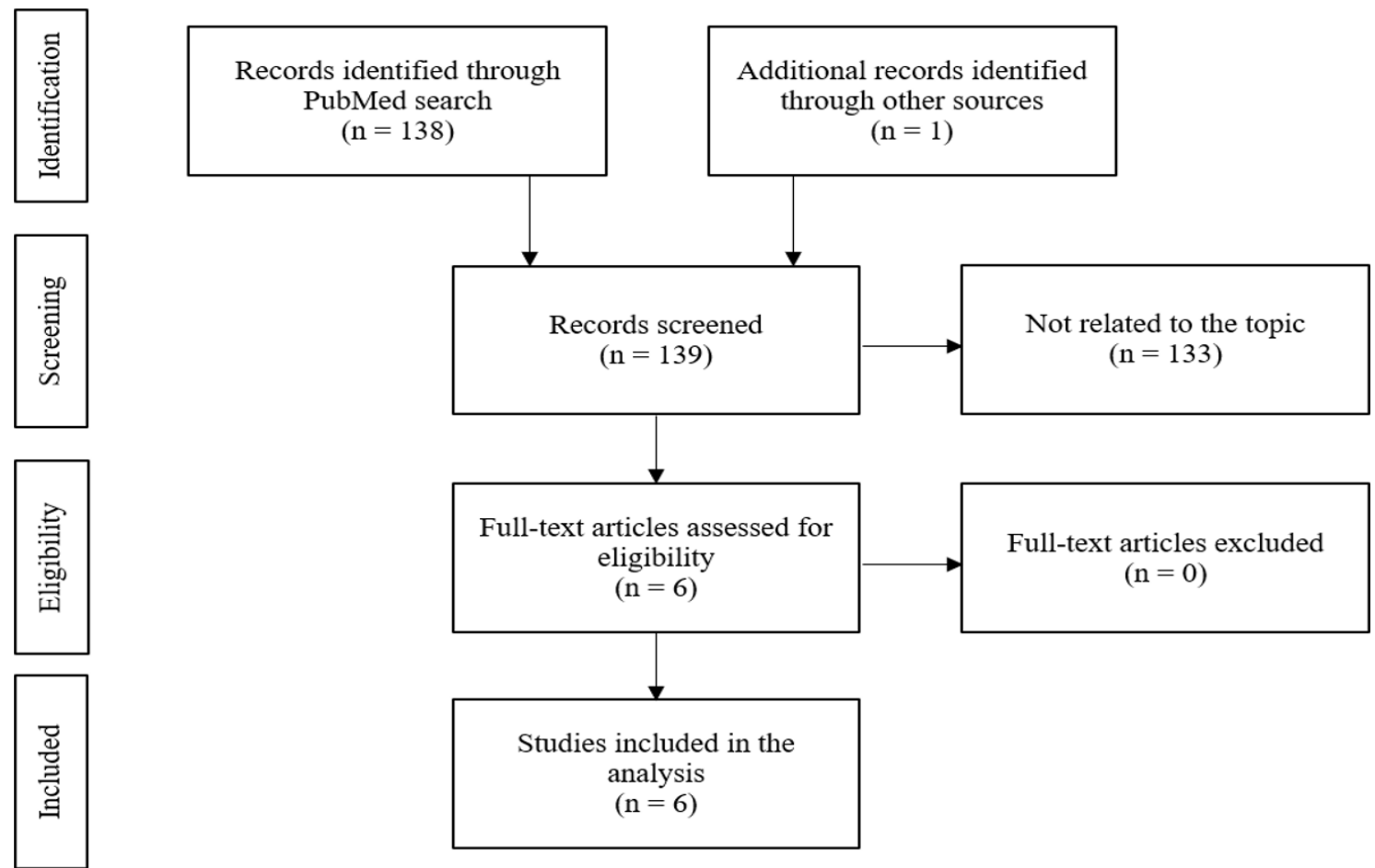

Figure 1. Flow diagram of the systematic review according to PRISMA guidelines.

optical coherence tomography (OCT) findings from Marinho et al. (2020) may not be related to COVID-19 and may represent normal retinal vessels. ${ }^{27}$ Aiello et al. (2020) proposed that due to RAAS protein expression in different ocular tissues, SARS-CoV-2 may be responsible for other possible ocular manifestations as retinal vasculitis. ${ }^{28}$ Table 2 summarizes the proposed pathogenesis of retinal manifestations in COVID-19 from each study.

\section{Discussion}

Coronaviruses consist of four structural proteins; spike $(\mathrm{S})$, membrane (M), envelope (E), and nucleocapsid $(\mathrm{N})$. The interaction between the spike protein and ACE-2, which was identified as a functional receptor for SARS-CoV-2, is the entry mechanism of the virus into the host cell. ACE-2 expression is high in the lung, heart, ileum, kidney, and bladder. ${ }^{4}$ However, some ocular structures are found to also express the ACE-2, including the aqueous humor, the pigmented epithelium, and the retina. ${ }^{28}$

There are reports regarding findings of SARSCoV-2 in the conjunctival secretion, which then manifested as conjunctivitis. However, there is limited evidence of the expression of spike protein/ ACE-2 receptor interaction in the conjunctiva and retina. ${ }^{28} \mathrm{~A}$ study conducted by Casagrande et al. (2020) showed evidence of SARS-CoV-2 nucleic acid detection in the human retina in postmortem patients. ${ }^{26}$ It was also identified that the binding of the spike protein/ ACE-2 receptor was promoted by serine protease TMPRSS2. However, the expressions of ACE-2 and TMPRSS-2 were found to be low in the human retinal cells.

In contrast to ACE-2, the transmembrane glycoprotein CD147 was expressed at moderate-high levels in the human retina especially in the retinal GC layer which has recently been reported as a novel invasive route for SARS-CoV-2. This protein mediates the breakdown of the blood-retinal barrier in the hyperglycemic state, which then may facilitate the invasion of SARS-CoV-2 into the retinal cells. ${ }^{26}$ This may explain the increased risk of retinal involvement in COVID-19 patients with DM.

In this systematic review, one study suggested COVID-19 patients with comorbidities had a poorer 
Table 1. Summary of the current research findings

\begin{tabular}{|c|c|c|c|c|c|c|c|}
\hline No. & Author & $\begin{array}{l}\text { Publication } \\
\text { date }\end{array}$ & Article type & Journal & $\begin{array}{l}\text { Total } \\
\text { subjects }\end{array}$ & $\begin{array}{l}\text { Median } \\
\text { or range } \\
\text { of age } \\
\text { (years) }\end{array}$ & Method \\
\hline 1. & $\begin{array}{l}\text { Marinho et } \\
\text { al. (20) }\end{array}$ & $12-5-2020$ & Correspondence & Lancet & 12 & $25-69$. & OCT \\
\hline 2. & $\begin{array}{l}\text { Landecho et } \\
\text { al. (24) }\end{array}$ & $30-7-2020$ & Original article & $\begin{array}{l}\text { Journal of Internal } \\
\text { Medicine }\end{array}$ & 27 & 59.8 & $\begin{array}{l}\text { OCT and OCT } \\
\text { angiography }\end{array}$ \\
\hline 3. & $\begin{array}{l}\text { Casagrande } \\
\text { et al. (25) }\end{array}$ & $29-5-2020$ & Original article & $\begin{array}{l}\text { Ocular Immunology } \\
\text { and Inflammation }\end{array}$ & 14 & $77 \pm 13.9$ & RT-PCR \\
\hline 4 & $\begin{array}{l}\text { Raony and } \\
\text { Saggioro de } \\
\text { Figueiredo } \\
\text { (26) }\end{array}$ & $25-6-2020$ & Letter to the editor & $\begin{array}{l}\text { Diabetes Research } \\
\text { and Clinical Practice }\end{array}$ & $\mathrm{n} / \mathrm{a}$ & $\mathrm{n} / \mathrm{a}$ & $\mathrm{n} / \mathrm{a}$ \\
\hline 5 & $\begin{array}{l}\text { Vavvas et al. } \\
\text { (27) }\end{array}$ & $9-7-2020$ & Editorial & $\begin{array}{l}\text { The Royal College of } \\
\text { Ophthalmologists }\end{array}$ & $\mathrm{n} / \mathrm{a}$ & $\mathrm{n} / \mathrm{a}$ & $\mathrm{n} / \mathrm{a}$ \\
\hline 6 & $\begin{array}{l}\text { Aiello et al. } \\
\text { (28) }\end{array}$ & $18-5-2020$ & Review & $\begin{array}{l}\text { The Royal College of } \\
\text { Ophthalmologists }\end{array}$ & $\mathrm{n} / \mathrm{a}$ & $\mathrm{n} / \mathrm{a}$ & $\mathrm{n} / \mathrm{a}$ \\
\hline
\end{tabular}

Note: $\mathrm{n} / \mathrm{a}$, data not available. OCT: optical coherence tomography; RT-PCR: real-time reverse transcriptase-polymerase chain reaction.

Table 2. Summary of the proposed pathogenesis of retinal manifestations in COVID-19

\begin{tabular}{lll}
\hline No. & Author & Proposed pathogenesis of retinal manifestations in COVID-19 \\
\hline 1. & Marinho et al. (20) & $\begin{array}{l}\text { Hyper-reflective lesions at the level of ganglion cell and inner plexiform layer can be } \\
\text { associated with CNS manifestations of SARS-CoV-2 infection. }\end{array}$ \\
2. $\quad$ Landecho et al. (24) & $\begin{array}{l}\text { Diabetic retinopathy is associated with a renin-angiotensin-aldosterone axis imbalance. } \\
\text { SARS-CoV-2 downregulates the ACE-2 receptor that might play a crucial role in inducing } \\
\text { retinal ischemia. }\end{array}$ \\
3. $\quad$ Casagrande et al. (25) & $\begin{array}{l}\text { Since the ACE-2 receptor is expressed in the retina, SARS-CoV-2 is very likely to infect the } \\
\text { retina. However, the detection of SARS-CoV-2 in retinal cells by in situ hybridization or viral }\end{array}$ \\
replication was not performed.
\end{tabular}

Note: ACE-2: Angiotensin-converting enzyme 2; OCT: optical coherence tomography; TMPRSS2: Transmembrane serine protease 2.

prognosis compared to COVID-19 patients without comorbidities. The most prevalent comorbidity associated with increased severity of COVID-19 is DM. Patients with DM have impaired immunity, hence increasing the risk of SARS-COV-2 infection. Huang et al. (2020) conducted a systematic review and meta-analysis to investigate the association between
DM and poor prognosis of patients with COVID-19 pneumonia. ${ }^{29}$ The results showed that DM was associated with a poor outcome, including a higher mortality rate, severe COVID-19, ARDS, and disease progression. It was also found that DM is a single risk factor that leads to poorer outcomes for younger people without hypertension. Guo et al. (2020) 
showed that patients with COVID-19 pneumonia and DM were more severe in organ damage, inflammatory factors, and hypercoagulability. These conditions would most likely progress into a poorer prognosis. ${ }^{30}$

Diabetic retinopathy was the most common complication in DM patients, manifested as microangiopathy in the retinal layer. This was associated with inflammation in the retinal vasculature. Inflammatory cytokines such as Interleukin 6 (IL-6), Interleukin 8 (IL-8), and tumor necrosis factor-alpha (TNF- $\alpha$ ) were increased in patients with DM. Chemokines such as monocyte chemotactic protein-1 (MCP-1), and macrophage inflammatory protein-1alpha (MIP-1 $\alpha$ ) were also reported to be elevated in diabetic patients. These cytokines play a role in increasing the severity of diabetic retinopathy. ${ }^{31}$ It was reported that elevation of proinflammatory cytokines such as TNF- $\alpha$ and IL- 6 were also found in COVID-19 patients, a condition known as a 'cytokine storm', and was associated with the severity of COVID-19 disease. ${ }^{32}$ This finding suggested that the cytokine storm might play a role in creating lesions in the retina manifested as cotton wool spots. ${ }^{20,24}$ However, this study had insufficient evidence to analyze the association between diabetic COVID-19 patients with diabetic retinopathy pathogenesis. Henceforth, it is necessary to conduct further studies regarding the association between SARS-CoV-2 infection and diabetic retinopathy.

Patients with DM were often associated with hypertension. Pharmacotherapy such as ACE inhibitors (ACEIs) and angiotensin II receptor blockers (ARBs) are frequently used to control hypertension. Both ACEls and ARBs may lead to overexpression of ACE-2 receptors in patients taking these drugs. ${ }^{33}$ SoroPaavonen et al. (2012) conducted a study in which diabetic patients with vascular complications treated with ACEls showed increased ACE-2 activity, but the mRNA level was not measured. ${ }^{34}$ The expression of ACE- 2 receptors has been associated with SARSCoV-2 infection in which the patients would be susceptible to COVID-19 disease. The higher the receptor's expression, the more likely SARS-CoV-2 would enter the cells and hence promote a cytokine storm. This raises the concern that diabetic patients treated with ACEIs or ARBs may lead to a higher risk of infection and increased morbidity and mortality. ${ }^{35}$ It could also involve overexpression of ACE- 2 receptors in the retina, in which SARS-CoV-2 would be able to bind and enter retinal cells. Furthermore, systemic inflammation that occurs in COVID-19 infection may also lead to retinal lesions. Though there are still some questions regarding the benefits and harm of ACEls and ARBs among diabetic COVID-19 patients, good diabetes management itself, such as blood glucose level control, would be necessary for treating these patients. Further studies are recommended to investigate the correlation between ACEls and ARBs given to diabetic patients and the overexpression of ACE- 2 receptors in the retina.

\section{Conclusion}

Although COVID-19 manifests mainly in the respiratory system, we cannot rule out the possibility of the SARS-CoV-2 invasion to other organs. Some evidence exists of retinal involvement in SARS-CoV-2 infection and its possible pathogenesis, however, more data are needed. There was a possible role of comorbidities and its treatments such as ACEls and ARBs in increasing the risk of retinal involvement in COVID-19 infection, though this possibility still needs to be investigated further.

\section{References}

1. World Health Organization (WHO). Weekly Operational Report on COVID-19 4 September 2020.[Internet] Cited 20 October 2020. Available from: https://www.who.int/docs/ default-source/coronaviruse/situationreports/wou-4-september-2020-approved. pdf?sfvrsn $=91215 c 78 \_2$

2. Cui J, Li F, Shi ZL. Origin and evolution of pathogenic coronaviruses. Nat Rev Microbiol. 2019;17:181-192.

3. World Health Organization. Archived: WHO Timeline - COVID-19. [Internet] Cited 20 October 2020. Available from: https://www.who.int/ news-room/detail/27-04-2020-who-timeline--covid-19

4. Yuki, K., Fujiogi, M., Koutsogiannaki, S. COVID-19 pathophysiology: a review. Clinical Immunology. 2020;215:108427. 
5. Lai CC, Shih TP, Ko WC, et al; Severe acute respiratory syndrome coronavirus 2 (SARS-CoV-2) and coronavirus disease-2019 (COVID-19): the epidemic and the challenges. Int J Antimicrob Agents. 2020;55(3):105924.

6. Wiersinga, WJ, Rhodes, A, Cheng, AC, Peacock, SJ, Prescott, HC. Pathophysiology, transmission, diagnosis and treatment of coronavirus disease 2019 (COVID-19): a review. JAMA. 2020;324(8):782-793.

7. Mao R, Qiu Y, He JS, Tan JY, Li XH, Liang J, et al. Manifestations and prognosis of gastrointestinal and liver involvement in patients with COVID-19: A systematic review and meta-analysis. Lancet Gastroenterol Hepatol. 2020; 5(7):667-678.

8. Guan WJ, Ni ZY, Hu Y, Liang W, Ou C, He J, et al; Clinical characteristics of coronavirus disease 2019 in China. N Engl J Med. 2020;382(18):17081720.

9. Garg S, Kim L, Whitaker M, O'Halloran A, Cummings $C$, Hostein $R$, et al. Hospitalization rates and characteristics of patients hospitalized with laboratory-confirmed coronavirus disease 2019-COVID-NET, 14 States, March 1-30, 2020. MMWR Morb Mortal Wkly Rep. 2020;69(15):458464.

10. Richardson $S$, Hirsch JS, Narasimhan $M$, Crawford JM, McGinn T, Davidson KW, et al. Presenting characteristics, comorbidities, and outcomes among 5700 patients hospitalized with COVID-19 in the New York City area. JAMA. 2020;323(20):2052-2059.

11. Docherty $A B$, Harrison EM, Green CA, Hardwick HE, Pius R, Norman L, et al. Features of 20133 UK patients in hospital with COVID-19 using the ISARIC WHO Clinical Characterisation Protocol: prospective observational cohort study. BMJ. 2020;369:m1985.

12. Grasselli G, Zangrillo A, Zanella A, Antonelli $M$, Cabrini L, Castelli A, et al; COVID-19 Lombardy ICU Network. Baseline characteristics and outcomes of 1591 patients infected with SARSCoV-2 admitted to ICUs of the Lombardy Region, Italy. JAMA. 2020;323(16):1574-1581.

13. Huang $C$, Wang $Y$, Li $X$, Ren L, Zhao J, Hu Y, et al. Clinical features of patients infected with 2019 novel coronavirus in Wuhan, China. Lancet.
2020;395(10223):497-506. doi:10.1016/S01406736(20)30183-5

14. Long B, Brady WJ, Koyfman A, Gottlieb M. Cardiovascular complications in COVID-19. Am J Emerg Med. 2020;38(7):1504-1507. doi:10.1016/j.ajem.2020.04.048

15. Mao L, Jin H, Wang M, Hu Y, Chen S, He Q, et al. Neurologic manifestations of hospitalized patients with coronavirus disease 2019 in Wuhan, China. JAMA Neurol. 2020;77(6):1-9.

16. Helms J, Kremer S, Merdji H, Clere-Jehl R, Schenck $M$, Kummerlen $C$, et al. Neurologic features in severe SARS-CoV-2 infection. $N$ Engl J Med. 2020;382(23):2268-2270.

17. Hendren NS, Drazner MH, Bozkurt B, Cooper LT. Description and proposed management of the acute COVID-19 cardiovascular syndrome. Circulation. 2020;141(23):1903-1914.

18. Wu P, Duan F, Luo C, Liu Q, Qu X, Liang L, Wu $K$. Characteristics of ocular findings of patients with coronavirus disease 2019 (COVID-19) in Hubei Province, China. JAMA Ophthalmol. 2020;138(5):575-578.

19. Aiello F, Afflitto GG, Mancino R, Li JO, Cesareo $M$, Giannini $C$, et al. Coronavirus disease 2019 (SARS-CoV-2) and colonization of ocular tissues and secretions: a systematic review. Eye 2020;34(7):1206-1211.

20. Marinho PM, Marcos AA, Romano AC, Nascimento $\mathrm{H}$, Belfort R. Retinal findings in patients with COVID-19. Lancet 2020;395(10237):1610.

21. Hoffmann $M$, Kleine-Weber $H$, Schroeder $S$, Kruger N, Herrler T, Erichsen S, et al. SARS-CoV-2 cell entry depends on ACE 2 and TMPRSS 2 and is blocked by a clinically proven protease inhibitor. Cell. 2020;181(2):271-280.

22. Zou $X$, Chen K, Zou J, et al. Single-cell RNA-seq data analysis on the receptor ACE2 expression reveals the potential risk of different human organs vulnerable to 2019-nCoV infection, Front Med. 2020;14(2):185-192.

23. Cristelo C, Azevedo C, Marques JM, Nunes R, Sarmento B. SARS-CoV-2 and diabetes: new challenges for the disease. Diabetes Res Clin Pract 2020;164:108228.

24. Landecho MF, Yuste JR, Gándara E, Sunsundegui 
P, Quiroga J, Alcaide AB, et al. COVID-19 retinal microangiopathy as an in vivo biomarker of systemic vascular disease? J Intern Med. 2020;168:108395.

25. Casagrande $M$, Fitzek $A$, Püschel $K$, Aleshcheva $G$, Schultheiss H-P, Berneking L, et al. Detection of SARS-CoV-2 in human retinal biopsies of deceased COVID-19 patients. Ocul Immunol Inflamm. 2020;28(5):721-725.

26. Raony Í, Figueiredo CS. Retinal outcomes of COVID-19: Possible role of CD147 and cytokine storm in infected patients with diabetes mellitus. Diabetes Res Clin Pract. 2020;165:108280.

27. Vavvas DG, Sarraf D, Sadda SR, Eliott D, Ehlers $J P$, Waheed NK, et al. Concerns about the interpretation of OCT and fundus findings in COVID-19 patients in recent Lancet publication. Eye Lond Engl. 2020;34(12):2153-2154.

28. Aiello F, Gallo Afflitto G, Mancino R, Li J-PO, Cesareo M, Giannini C, et al. Coronavirus disease 2019 (SARS-CoV-2) and colonization of ocular tissues and secretions: a systematic review. Eye. 2020;34:1206-1211.

29. Huang I, Lim MA, Pranata R. Diabetes mellitus is associated with increased mortality and severity of disease in COVID-19 pneumonia - A systematic review, meta-analysis, and metaregression. Diabetes Metab Syndr. 2020;14:395-403. doi: 10.1016/j.dsx.2020.04.018

30. Guo W, Li M, Dong Y, Zhou H, Zhang Z, Tian C, et al. Diabetes is a risk factor for the progression and prognosis of COVID-19. Diabetes Metab Res Rev 2020;e3319.

31. Wang W, Lo AC. Diabetic retinopathy: pathophysiology and treatments. Int J Mol Sci 2018;19(6):1816.

32. Ye $Q$, Wang $B$, Mao J. The pathogenesis and treatment of the 'cytokine storm' in COVID-19. J Infect 2020;80(6):607-613.

33. Cristelo C, Azevedo C, Marques JM, Nunes R, Sarmento B. SARS-CoV-2 and diabetes: New challenges for the disease. Diabetes Res Clin Pract 2020;164:108228.

34. Soro-Paavonen A, Gordin D, Forsblom C, et al. Circulating ACE2 activity is increased in patients with type 1 diabetes and vascular complications. J Hypertens 2012;30(2):375-383.
35. Fang L, Karakiulakis G, Roth M. Are patients with hypertension and diabetes mellitus at increased risk for COVID-19 infection? Lancet Respirat Med 2020;8(4):e21. 